\title{
Development of a dietary index based on the Brazilian Cardioprotective Nutritional Program (BALANCE)
}

Jacqueline Tereza da Silva ${ }^{1,2^{*}}$, Ângela Cristine Bersch-Ferreira ${ }^{1,2}$, Camila Ragne Torreglosa ${ }^{1,2}$, Bernardete Weber $^{2}$ and Renata Bertazzi Levy ${ }^{1,3}$

\begin{abstract}
Background: The diet of the Brazilian Cardioprotective Nutritional Program (BALANCE) classifies food into four groups and sets the daily amount to be consumed. The dietary approach of BALANCE is different from other dietary recommendations; therefore, it is not possible to use existing dietary indexes (DI) to assess patient's adequacy to BALANCE diet. For this reason, it is important to develop a specific dietary index based on BALANCE diet. This study aims to describe the development of the BALANCE DI, evaluate its internal consistency, construct and content validity and population characteristics associated with the index.

Methods: We analyzed baseline data from the BALANCE randomized clinical trial (https://www.clinicaltrials.gov/; NCT01620398). The four food groups of the diet were adopted as index components. Points ranging from 0 to 10 were given to each index component. Internal consistency was evaluated by correlation coefficients between total score and component scores, as well as Cronbach's Alpha. Content and construct validity were assessed by checking how nutrients are associated with the index and if the index could distinguish between groups with known differences in diet, respectively. Crude and adjusted linear regression analyses were performed to evaluate population characteristics associated with the index.
\end{abstract}

Results: The analysis included 2044 subjects (58.6\% men). The average of the total index was higher among women $(p<0,05)$. The components of the index showed low correlations with each other. The correlations between each individual component with the total index were $>0.40$. Cronbach's alpha coefficient was 0.66 . High scores in the index were inversely associated $(p<0,05)$ with energy, total fat, monounsaturated fat (MUFA) and cholesterol; they were positively associated $(p<0,05)$ with carbohydrates and fiber. Hypertensive men and diabetic women had higher scores, while male smokers had lower scores.

Conclusions: The BALANCE DI showed reliability and construct validity similar to other DI. It also detected characteristics of individuals that are associated with higher or lower index scores.

Keywords: Dietary assessment, Nutritional index, dietary patterns, Reliability and validity, Cardiovascular disease

\footnotetext{
* Correspondence: jacsnt@yahoo.com.br

'Department of Nutrition, School of Public Health, University of São Paulo,

Avenida Doutor Arnaldo, 715, São Paulo, SP 01246904, Brazil

${ }^{2}$ Research Institute, Hospital do Coração (HCor), Rua Abílio Sorares, 250, $12^{\circ}$

andar, São Paulo, SP 04005-000, Brazil

Full list of author information is available at the end of the article
}

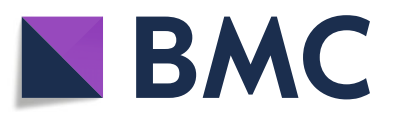

(c) The Author(s). 2018 Open Access This article is distributed under the terms of the Creative Commons Attribution 4.0 International License (http://creativecommons.org/licenses/by/4.0/), which permits unrestricted use, distribution, and reproduction in any medium, provided you give appropriate credit to the original author(s) and the source, provide a link to the Creative Commons license, and indicate if changes were made. The Creative Commons Public Domain Dedication waiver (http://creativecommons.org/publicdomain/zero/1.0/) applies to the data made available in this article, unless otherwise stated. 


\section{Background}

Dietary habits are important modifiable risk factors for cardiovascular diseases (CVD), the first cause of death and burden of disease worldwide and in Brazil $[1,2]$. The World Health Organization (WHO) emphasizes that a healthy diet, able to prevent CVD, is influenced by many complex interactions (income, food availability and affordability, individual preferences and beliefs, cultural traditions, geographical, environmental, social and economic factors) [3]. To take these complex interactions into account, the choice of foods that compose a healthy and cardioprotective diet should be regionalized.

Brazil has a variety of food rich in cardioprotective components such as fiber, vitamins and bioactive compounds that could be used to promote cardiovascular protection and minimize the burden of CVD. The Brazilian Cardioprotective Nutritional Program (BALANCE) is an educational intervention aimed at improving the consumption of foods available in the country with a potential cardioprotective role. The Brazilian Ministry of Health has been assessing the effectiveness of the BALANCE program in a multicentric and randomized clinical trial since 2013 [4].

The dietary component of the BALANCE program ranked foods in groups represented by the colours of the Brazilian flag. As green is the most abundant colour in the flag, the items included in the green group should be eaten more often. Yellow is the second most abundant flag colour, thus the advice is to eat foods in the yellow group in moderation. Blue represents foods that should be consumed in smaller quantities. Ultra-processed foods are not recommended in the BALANCE diet and are represented by red, which is not in the Brazilian flag. Details about the food classification criteria have been published elsewhere [4].

Several dietary indexes (DI) have been developed to study associations between dietary patterns and CVD in different populations [5-10]. A DI combines the many aspects of a nutritional recommendation or guideline and uses them as the items of the index. These aspects are generally the amount of nutrients, foods or food groups to be eaten in each period of time (day/week/ month). Since the dietary aspects of the BALANCE program are different from other cardioprotective dietary patterns, it is not possible to use existing DI to assess the role of the BALANCE diet on cardiovascular protection. We therefore aim to describe the development of the BALANCE DI, to assess its internal consistency, construct and content validity, and to evaluate the population characteristics associated with the index.

\section{Methods}

\section{Study population}

To develop the DI we used data from the BALANCE study (https://www.clinicaltrials.gov/; NCT01620398), a multicentric randomized clinical trial. The trial aims to assess the effects of the Brazilian Cardioprotective Nutritional Program in the secondary prevention of cardiovascular diseases. Between March 2013 and January 2015, 2535 adults over 44-years-old and with a personal history of cardiovascular disease were enrolled in the trial and followed-up until December 2017 in one of the 35 sites in Brazil. Details of the trial procedures are given elsewhere [4]. The 2044 individuals who had full dietary data at baseline were included in the present analysis, which was approved by the School of Public Health/University of São Paulo Research Ethics Committee.

\section{Data collection and description of variables}

Data were collected in the 35 sites by trained researchers following standardized procedures. Details of the data collection are given in the BALANCE research protocol, available on request from the authors [4].

Dietary intake was assessed from a single 24-h recall collected by trained interviewers who asked for a detailed description of all foods and drinks consumed the day before the interview, following an adaptation of the Multiple-Pass Method steps [11]. A photographic album of food portion sizes was available to help with the estimation of quantities of food consumed [12]. The food intake data was recorded in Nutriquanti Software using household measures and then converted to grams. The software calculated the energy and nutrient amount using information from different food composition tables, including the Brazilian Food Composition Table and the USDA Food Composition Table. All the 24-h recalls that ranged over less than $1000 \mathrm{kcal}$ or more than $3000 \mathrm{kcal}$ were double-checked. Discrepant home measures, such as "zero tablespoon" and "150 teacups" were also double-checked. Records with less than the 1st or greater than the 99th percentile of energy were excluded [13]. The relative participation of macronutrients in the diet was expressed as the percentage of total energy intake. Cholesterol, sodium and fiber were presented as milligrams or grams per each $1000 \mathrm{kcal}$ ingested.

Height was measured twice with wall-mounted stadiometers $(0.5 \mathrm{~cm}$ precision) with the subject barefoot in a standing position. Weight was collected twice with calibrated scales (100 g precision) with the subject barefoot and wearing light clothes. Waist circumference (WC) was measured twice with an anthropometric tape in the midpoint between the lowest rib and the iliac crest. The average of the measurements was used. If the measurements differed more than $0.5 \mathrm{~kg}$ for weight, $0.5 \mathrm{~cm}$ for height and $1 \mathrm{~cm}$ for $\mathrm{WC}$, the entire procedure was repeated until the difference between the two new measures was lower than the established cut-off. Body mass index (BMI) was calculated as weight divided by the square of height $\left(\mathrm{kg} / \mathrm{m}^{2}\right)$ and classified according to age. 
If age $\leq 59$ years-old, underweight $=\mathrm{BMI}<18.5 \mathrm{~kg} / \mathrm{m}^{2}$, normal weight $=B M I \geq 18.5 \mathrm{~kg} / \mathrm{m}^{2}$ and $<25 \mathrm{~kg} / \mathrm{m}^{2}$, overweight $=\mathrm{BMI} \geq 25 \mathrm{~kg} / \mathrm{m}^{2}$ [14]. If age $\geq 60$ years-old, underweight $=\mathrm{BMI}<23 \mathrm{~kg} / \mathrm{m}^{2}$, normal weight $=\mathrm{BMI} \geq$ $23 \mathrm{~kg} / \mathrm{m}^{2}$ and $<28 \mathrm{~kg} / \mathrm{m}^{2}$, overweight $=B M I \geq 28 \mathrm{~kg} / \mathrm{m}^{2}$ $[14,15]$.

A questionnaire was applied to investigate the personal history of CVD and smoking status. Diagnoses of diabetes, hypertension and dyslipidemia were self-reported.

\section{The dietary component of the BALANCE program}

The dietary component of the BALANCE program [4] is designed to meet the nutritional recommendations proposed by the Brazilian Cardiovascular Guidelines [16-20]. To implement these recommendations on nutritional advice, we compiled a list of cardioprotective foods, based on a set of qualitative criteria defined by nutrition experts considering the most relevant aspects of Brazilian nutritional guidelines: a) no added sugar; b) low-calorie content; c) lack of nutrients that increase cardiovascular risk (cholesterol, saturated fat, and sodium); and d) presence of cardioprotective nutrients (antioxidants and dietary fiber). The result of the compilation was a list consisting of low-fat yoghurt and milk, fruits and vegetables, and beans cooked with garlic, onion, soybean oil (up to $1 \%$ ) and refined salt (up to $0.5 \%$ ).

Energy, saturated fat, cholesterol and sodium densities [21] of foods in the list were evaluated to create cutoff values for food classification into the green, yellow and blue groups. The maximum density values of the list were $1.11 \mathrm{kcal}$ per gram, $0.01 \mathrm{~g}$ of saturated fatty acid per gram, $0.04 \mathrm{mg}$ of cholesterol per gram, and $2.01 \mathrm{mg}$ of sodium per gram. These values were applied in the food categorization as follows: foods with all 4 density values equal to or less than the cutoffs were assigned to the green group (vegetables, fruits, beans, low-fat milk and yoghurt); foods with one or two densities above the cutoffs were assigned to the yellow group (rice, bread, pasta, oats, couscous, nuts, vegetable oil); foods with three or four nutrient densities above the cutoffs were categorized into the blue group (meat, fish, cheese, eggs).
Finally, the BALANCE diet contains a red group. The cutoffs were not adopted as criteria for assigning foods in this group. Instead, foods lacking beneficial components such as vitamins, antioxidants and dietary fiber and known as sources of trans fats, refined sugar, artificial sweeteners, and preservatives - mainly ultraprocessed foods - compose the red group.

\section{The BALANCE dietary index}

We created the BALANCE DI considering the aspects of the existing DI that are used to analyze associations between dietary patterns and cardiovascular disease [7, 22-25]. The BALANCE Program recommends a number of servings in each food group depending on the energy level, as shown in Table 1. Energy need was calculated multiplying current body weight by $20 \mathrm{kcal}$ in overweight or $25 \mathrm{kcal}$ in normal weight or $32 \mathrm{kcal}$ in underweight participants $[17,26]$. Individuals with calculated need below $1400 \mathrm{kcal}$ were set to $1400 \mathrm{kcal}$, those above $2400 \mathrm{kcal}$ were set to $2400 \mathrm{kcal}$. Intermediate values were assessed accordingly to mathematical approximation rules. For example, if the calculated need is $1758 \mathrm{kcal}$, the nutritionist must assign into the $1800 \mathrm{kcal}$, the closest value.

The index has four components corresponding to the BALANCE food groups. The scoring criteria are summarized in Table 2 and were made a priori, based on the BALANCE principles and recommendations and the population distribution of consumed servings. Each component was given a score ranging from 0 (worst) to 10 (best), therefore the total score ranges from 0 to 40 .

A score of zero is given to the green group when there is no consumption and a score of 10 when the consumption is equal or higher than the recommendation. A score of 10 is assigned to the yellow group when the number of servings is exactly that recommended. The minimum score is assigned to the yellow group when the number of servings is $50 \%$ over or below the recommendation. The blue and red groups received a reverse score (higher intakes are given lower scores). In the blue group, the maximum score is assigned to the number of servings equal to or lower than the recommendation

Table 1 BALANCE recommendation of servings per day in each food group according to the energy-level ${ }^{a}$

\begin{tabular}{llllll}
\hline & \multicolumn{3}{l}{ Number of servings per day } \\
\cline { 2 - 6 } BALANCE food groups & 1400 & 1600 & 1800 & 2000 & 2200 \\
Kreen (vegetables, fruits, beans and legumes, low-fat milk) & 9 & Kcal & Kcal & Kcal & Kcal \\
Yellow (rice, bread, pasta, oats, couscous, nuts, vegetable oil) & 6 & 11 & 11 & 12 & 14 \\
Blue (meat, fish, cheese, eggs) & 2 & 2 & 9 & 10 & 11 \\
Red (ultra-processed foods) & 0 & 0 & 0 & 3 & 4 \\
\hline
\end{tabular}

BALANCE $=$ Brazilian Cardioprotective Nutritional Program

${ }^{a}$ This content was published in the BALANCE research protocol, is reproduced with permission and available on request from the authors [14] 
Table 2 Scoring criteria for the BALANCE dietary index, mean score (95\% confidence interval) among men and women with a history of cardiovascular disease

\begin{tabular}{|c|c|c|c|c|}
\hline Index component (BALANCE food group) & Criteria for 0 point ${ }^{*}$ & Criteria for 10 point* & Score for men & Score for women \\
\hline $\begin{array}{l}\text { Green (vegetables, fruits, beans and legumes, } \\
\text { low-fat milk) }\end{array}$ & 0 & $\geq$ the recommendation & $4.49(4.34 ; 4.65)$ & $4.55(4.36 ; 4.73)$ \\
\hline $\begin{array}{l}\text { Yellow (rice, bread, pasta, oats, couscous, nuts, } \\
\text { vegetable oil) }\end{array}$ & $\begin{array}{l}50 \%>\text { or }<\text { the } \\
\text { recommendation }\end{array}$ & $=$ the recommendation & $3.50(3.30 ; 3.69)$ & $3.52(3.29 ; 3.74)$ \\
\hline Blue (meat, fish, cheese, eggs)** & $\begin{array}{l}\geq 2 \text { beyond the } \\
\text { recommended }\end{array}$ & $\leq$ the recommendation & $5.20(4.95 ; 5.46)$ & $6.09(5.80 ; 6.38)$ \\
\hline Red (ultra-processed foods) ${ }^{* *}$ & $\geq 4$ & $\leq 0$ & $5.37(5.14 ; 5.61)$ & $5.90(5.64 ; 6.16)$ \\
\hline Total score $(\text { range })^{* *}$ & 0 & 40 & $18.56(18.11 ; 19.02)$ & $20.05(19.54 ; 20.56$ \\
\hline
\end{tabular}

BALANCE $=$ Brazilian Cardioprotective Nutritional Program

*Servings/d between the minimum and maximum criteria were given the scores proportionally

**Statistical differences between means $p<0.05$ (Mann-Whitney test)

and the minimum when there are at least two servings above the recommendation. Finally, in the red group, a score of 10 is assigned when there is no consumption, and a score of 0 is given to 4 or more reported servings. Those participants consuming intermediate amounts were scored proportionally.

To calculate the score, we classified all food items reported in the 24-h recalls into the BALANCE food groups and defined the size of a serving. Then, we calculated the number of servings consumed and the corresponding score for each component. Finally, we summarized the component values to obtain the total score.

Because the BALANCE DI was developed to assess the consistency with the BALANCE Program dietary component, we decided to follow the rationale of the Program and use the BALANCE food groups as the items of the score. The foods in the green group have low energy, saturated fat, cholesterol and sodium density and higher levels of cardioprotective compounds [4]. Furthermore, the consumption of these foods is low in the Brazilian population [27] and we aim to improve the intake of such foods. For this reason, we did not assign a penalty for overconsumption and used a monotonic function to score this component (higher levels of intake received higher scores).

As the yellow group is the major provider of energy intake, we believe the consumption should be neither higher nor lower than the recommendation, to maintain the energy balance. Hence, the scoring system has two directions with intakes under or above the recommendation being penalized.

The blue group is mainly responsible for the saturated fat, cholesterol and sodium intake and received a reverse score (higher intakes get lower scores). The red group is not recommended in the BALANCE diet and therefore also gets a reverse score. For these items in the index there is no clear scientific evidence determining what amount of intake should receive the minimum score of zero. To improve discriminatory power and the ability to detect differences in the population, we determined, as the cutoff, an approximate value of the 75th percentile of the population intake distribution. A similar strategy has been adopted in previous studies [28].

\section{Statistical analysis}

The scores of the overall index and its components were described in mean and 95\% confidence interval (95\% CI) for males and females and differences were assessed by Mann-Whitney tests. Subsequent analyses were performed separately by sex because the scores differed among men and women.

To evaluate the internal consistency of the index we analyzed the inter-item correlation matrix, and calculated the Spearman rank correlation coefficients between the components and total index. We also estimated the Cronbach's coefficient alpha. Values higher than 0.70 indicated reliability (internal consistency).

To assess construct validity, we checked if the index could distinguish between groups with known differences in diet (men and women). To assess the content validity, we verified if the index was associated with key nutrients in an expected direction, dividing it into quartiles and calculating the mean and 95\% CI of energy and selected nutrient intakes in each quartile. The fourth quartile indicated the highest adequacy with the BALANCE, whereas the first quartile indicated the lowest adequacy with the diet. Tests for linear trends were performed to compare the population intakes across the quartiles.

The population characteristics associated with the index were assessed by linear regression, crude and adjusted for age, BMI, waist circumference, hypertension, dyslipidemia, diabetes and smoking status. All the analyses were conducted in STATA software, version 12, and statistical significance was defined as $p<0.05$. 


\section{Results}

The analysis included 2044 subjects with a mean (standard deviation) age of 63 [9] years. Among males (58.6\% of the population), $88.3 \%$ were hypertensive, $78.5 \%$ dyslipidemic, $41.9 \%$ diabetic, $63.3 \%$ former smoker and $7.4 \%$ current smoker and the mean (SD) of BMI and WC was, respectively, $28.5(4.4) \mathrm{Kg} / \mathrm{m}^{2}$ and $101.1(11.3) \mathrm{cm}$. Among females, 93.2\% were hypertensive, 79.0\% dyslipidemic, 45 . $7 \%$ diabetic, $41.6 \%$ former smoker and $8.0 \%$ current smoker and the mean (SD) of BMI and WC was, respectively, $29.8(5.5) \mathrm{Kg} / \mathrm{m}^{2}$ and $97.9(12.9) \mathrm{cm}$.

Table 2 describes the criteria for minimum and maximum score in each component of the BALANCE DI and shows the mean $(95 \% \mathrm{CI})$ for the components and total score among men and women. The results differed between sexes, with females having higher scores in the total index, and in the blue and red components (Table 2). The findings for the green and yellow groups were similar in both sexes.

The correlations among BALANCE DI components and total index are shown in Table 3. The components of the index had low correlations among themselves $(r<0.10)$. The blue and red groups showed similar correlations with the total index $(r=0.61$ and $r=0.62$, respectively) and were more correlated with the total index than the other components, indicating that their variance contributes more to the total score. Nevertheless, the green and yellow groups do add important information to the total score as they show correlations higher than 0.40. The Cronbach's coefficient alpha of the BALANCE dietary index was 0.66 .

Table 4 presents the mean $(95 \% \mathrm{CI})$ of energy and selected nutrient intakes across quartiles of the BALANCE index among men and women. Higher scores were inversely associated with intakes of energy, total fat, MUFA and cholesterol and positively associated with intakes of carbohydrate and fiber. Among males, there was no difference in the consumption of proteins across the quartiles of the score and among females, the intake of protein was higher in the 4th quartile. No difference was observed in the intake of polyunsaturated fat and sodium.

Table 5 presents population characteristics associated with the index. In general, males with hypertension and females with diabetes had higher scores in the index, while male smokers had lower scores. On average, the adjusted analyses showed hypertensive men having 1.77 higher scores than non-hypertensives, male current smokers had 2.13 lower scores compared with males who never smoked and diabetic women had 1.56 higher scores than non-diabetics.

\section{Discussion}

BALANCE DI was developed to reflect the recommendations of the dietary component of the BALANCE Program. The index showed reasonable internal consistency, construct and content validity and detected population characteristics associated with higher or lower scores.

The ability to detect known differences in the population corroborates the construct validity of a DI [25]. It is well known that women in general eat more healthily than men and the BALANCE DI found variations across sex, with women having higher scores in the total index. This finding is consistent with previous studies assessing different diet indexes, which also observed women having a more favorable diet [25, 28-30]. The higher consumption of fruits and vegetables by women is usually the reason they obtain better scores in DI [28]. However, our study showed no differences in the consumption of fruits and vegetables (green food group) across sex, but found lower consumption of meat (blue food group) and ultra-processed foods (red food group) among women. The BALANCE DI also detected differences in the diet between smoker and non-smoker males. On average, smokers had lower scores than non-smokers.

The Cronbach's coefficient alpha measures the internal consistency and values higher than 0.70 indicate accepted reliability. Similar to other studies which found alphas between 0.6 and 0.7 [25, 31], the alpha coefficient for the BALANCE DI was 0.66. According to Guenther and colleagues [25], given the complex and multidimensional construct of DI and because individuals do not fully meet and do not fully fail to meet all the dietary standards used in the indexes, an alpha coefficient slightly lower than 0.70 is expected. The low inter-item correlation $(r<0.10)$ and correlations $\geq 0.40$ between each item and total index strengthen the reliability of the index.

Table 3 Correlation between BALANCE diet components and total index

\begin{tabular}{lllll}
\hline & Green group & Yellow group & Blue group & Red group \\
\hline Green group & 1 & & & \\
Yellow group & 0.0113 & 1 & & \\
Blue group & 0.0096 & 0.0053 & 1 & 1 \\
Red group & 0.0883 & 0.0430 & 0.0892 & 0.6157 \\
Total index & 0.4033 & 0.4594 & 0.6131 & 1 \\
\hline
\end{tabular}

BALANCE = Brazilian Cardioprotective Nutritional Program. Green group = vegetables, fruits, beans and legumes, fat free milk and yogurt. Yellow = rice, bread, pasta, oats, couscous, nuts, vegetable oil. Blue = meat, fish, cheese, eggs. Red = ultra-processed foods 
Table 4 Energy and selected nutrient intake (mean and 95\% confidence interval) across quartiles of the BALANCE dietary index among men and women with a history of cardiovascular disease

\begin{tabular}{|c|c|c|c|c|c|c|c|c|}
\hline \multirow[t]{2}{*}{ Dietary component } & \multicolumn{4}{|l|}{ MEN } & \multicolumn{4}{|l|}{ WOMEN } \\
\hline & 1 & 2 & 3 & 4 & 1 & 2 & 3 & 4 \\
\hline $\mathrm{n}$ & 300 & 299 & 299 & 299 & 211 & 212 & 212 & 212 \\
\hline BALANCE index range & $0 ; 13.31$ & $13.32 ; 18.33$ & $18.34 ; 24.79$ & $24.80 ; 38.62$ & $0 ; 14.51$ & $14.52 ; 20.54$ & $20.55 ; 25.59$ & $25.61 ; 39.59$ \\
\hline Energy, Kcal & $\begin{array}{l}1851 \\
(1777 ; 1926)\end{array}$ & $\begin{array}{l}1629 \\
(1560 ; 1697)\end{array}$ & $\begin{array}{l}1453 \\
(1396 ; 1509)\end{array}$ & $\begin{array}{l}1345 \\
(1293 ; 1398)\end{array}$ & $\begin{array}{l}1498 \\
(1416 ; 1579)\end{array}$ & $\begin{array}{l}1279 \\
(1206 ; 1351)\end{array}$ & $\begin{array}{l}1213 \\
(1140 ; 1287)\end{array}$ & $\begin{array}{l}1169 \\
(1116 ; 1221)\end{array}$ \\
\hline Protein, \% Kcal & $\begin{array}{l}19.2 \\
(18.4 ; 20.0)\end{array}$ & $\begin{array}{l}19.2 \\
(18.3 ; 19.8)\end{array}$ & $\begin{array}{l}19.2 \\
(18.5 ; 19.9)\end{array}$ & $\begin{array}{l}18.3 \\
(17.7 ; 18.9)^{1}\end{array}$ & $\begin{array}{l}17.5 \\
(16.6 ; 18.5)\end{array}$ & $\begin{array}{l}18.7 \\
(17.9 ; 19.7)\end{array}$ & $\begin{array}{l}17.8 \\
(17.1 ; 18.6)\end{array}$ & $\begin{array}{l}18.8 \\
(18.1 ; 19.6)\end{array}$ \\
\hline $\begin{array}{l}\text { Carbohydrate, } \\
\% \text { Kcal }\end{array}$ & $\begin{array}{l}48.0 \\
(46.6 ; 49.3)\end{array}$ & $\begin{array}{l}50.8 \\
(49.6 ; 52.0)\end{array}$ & $\begin{array}{l}54.6 \\
(53.4 ; 55.8)\end{array}$ & $\begin{array}{l}58.7 \\
(57.5 ; 59.9)\end{array}$ & $\begin{array}{l}51.3 \\
(49.8 ; 52.7)\end{array}$ & $\begin{array}{l}54.1 \\
(52.7 ; 55.6)\end{array}$ & $\begin{array}{l}57.2 \\
(55.6 ; 58.8)\end{array}$ & $\begin{array}{l}59.3 \\
(57.8 ; 60.7)\end{array}$ \\
\hline $\begin{array}{l}\text { Total fat, } \\
\% \text { Kcal }\end{array}$ & $\begin{array}{l}32.9 \\
(31.9 ; 33.8)\end{array}$ & $\begin{array}{l}30.8 \\
(29.9 ; 31.8)\end{array}$ & $\begin{array}{l}27.2 \\
(26.3 ; 28.1)\end{array}$ & $\begin{array}{l}24.9 \\
(24.0 ; 25.8)\end{array}$ & $\begin{array}{l}31.7 \\
(30.5 ; 32.9)\end{array}$ & $\begin{array}{l}28.2 \\
(27.0 ; 29.4)\end{array}$ & $\begin{array}{l}26.9 \\
(25.7 ; 28.2)\end{array}$ & $\begin{array}{l}24.1 \\
(23.0 ; 25.2)\end{array}$ \\
\hline $\begin{array}{l}\text { Saturated, } \\
\% \text { Kcal }\end{array}$ & $\begin{array}{l}10.9 \\
(10.5 ; 11.3)\end{array}$ & $\begin{array}{l}8.4 \\
(9.4 ; 10.1)\end{array}$ & $\begin{array}{l}8.4 \\
(8.0 ; 8.8)\end{array}$ & $\begin{array}{l}7.1 \\
(6.8 ; 7.5)\end{array}$ & $\begin{array}{l}11.0 \\
(10.5 ; 11.5)\end{array}$ & $\begin{array}{l}9.2 \\
(8.7 ; 9.7)\end{array}$ & $\begin{array}{l}8.4 \\
(7.9 ; 8.7)\end{array}$ & $\begin{array}{l}7.2 \\
(6.8 ; 7.7)\end{array}$ \\
\hline Monounsaturated, \% Kcal & $9.1(8.7 ; 9.5)$ & $9.8(8.2 ; 9.0)$ & $7.7(7.3 ; 8.1)$ & $6.9(6.6 ; 7.2)$ & $8.8(8.3 ; 9.2)$ & $7.5(7.0 ; 7.9)$ & $7.3(6.8 ; 7.8)$ & $6.9(6.3 ; 7.4)$ \\
\hline Polyunsaturated, \% Kcal & $7.5(7.1 ; 7.9)$ & $7.9(7.5 ; 8.4)$ & $7.4(7.1 ; 7.8)$ & $7.3(7.0 ; 7.7)^{1}$ & $6.9(6.4 ; 7.3)$ & $7.3(6.8 ; 7.8)$ & $7.1(6.6 ; 7.6)$ & $6.7(6.3 ; 7.1)^{1}$ \\
\hline Cholesterol, mg/1000 Kcal & $\begin{array}{l}162 \\
(149 ; 174)\end{array}$ & $\begin{array}{l}141 \\
(130 ; 152)\end{array}$ & $\begin{array}{l}133 \\
(121 ; 145)\end{array}$ & $\begin{array}{l}111 \\
(102 ; 120)\end{array}$ & $\begin{array}{l}147 \\
(134 ; 160)\end{array}$ & $\begin{array}{l}130 \\
(119 ; 141)\end{array}$ & $\begin{array}{l}113 \\
(101 ; 125)\end{array}$ & $\begin{array}{l}103 \\
(94 ; 112)\end{array}$ \\
\hline Sodium, mg/1000 Kcal & $\begin{array}{l}1922 \\
(1845 ; 2000)\end{array}$ & $\begin{array}{l}1818 \\
(1752 ; 1885)\end{array}$ & $\begin{array}{l}1860 \\
(1800 ; 1920)\end{array}$ & $\begin{array}{l}2090 \\
(1762 ; 2417)^{1}\end{array}$ & $\begin{array}{l}1760 \\
(1678 ; 1852)\end{array}$ & $\begin{array}{l}1873 \\
(1748 ; 1999)\end{array}$ & $\begin{array}{l}1798 \\
(1711 ; 1884)\end{array}$ & $\begin{array}{l}1777 \\
(1690 ; 1863)\end{array}$ \\
\hline Fiber, g/1000 Kcal & $\begin{array}{l}10.1 \\
(9.6 ; 10.6)\end{array}$ & $\begin{array}{l}12.3 \\
(11.8 ; 12.9)\end{array}$ & $\begin{array}{l}14.5 \\
(13.8 ; 15.1)\end{array}$ & $\begin{array}{l}17.8 \\
(17.0 ; 18.6)\end{array}$ & $\begin{array}{l}10.2 \\
(9.5 ; 10.9)\end{array}$ & $\begin{array}{l}13.2 \\
(12.4 ; 13.9)\end{array}$ & $\begin{array}{l}15.0 \\
(14.0 ; 16.0)\end{array}$ & $\begin{array}{l}17.2( \\
16.2 ; 18.2)\end{array}$ \\
\hline
\end{tabular}

BALANCE $=$ Brazilian Cardioprotective Nutritional Program. ${ }^{1}$ The $P$-value for linear trend was not significant $(\geq 0,05)$. All others were significant, $P<0,05$

The BALANCE DI showed association with energy and key nutrients in an expected direction, because it was inversely associated with intakes of energy, total fat, MUFA and cholesterol and it was positively associated with intakes of fiber and carbohydrate. These findings are consistent with previous diet quality indexes for Swedish, Australian and American population without cardiovascular disease [9, 29, 32], except the 14-point Mediterranean diet adherence screener which was inversely associated with carbohydrate and positively associated with MUFA [33]. In concordance with our findings, Mendes and colleagues found that higher intakes of total fat were significantly associated with lower index scores in the Healthy Eating Index for the Brazilian population [30].

The lower levels of MUFA in the highest quartile of the index were expected because the sources of MUFA in western diets are usually the same as the sources of

Table 5 Association between the BALANCE dietary index and characteristics of men and women with history of cardiovascular diseases

\begin{tabular}{|c|c|c|c|c|c|c|c|c|}
\hline \multirow{3}{*}{ Population characteristics } & \multicolumn{4}{|l|}{ MEN } & \multicolumn{4}{|l|}{ WOMEN } \\
\hline & \multicolumn{2}{|l|}{ Crude } & \multicolumn{2}{|l|}{ Adjusted $^{a}$} & \multicolumn{2}{|l|}{ Crude } & \multicolumn{2}{|l|}{ Adjusted $^{a}$} \\
\hline & Coefficient & $95 \% \mathrm{Cl}$ & Coefficient & $95 \% \mathrm{Cl}$ & Coefficient & $95 \% \mathrm{Cl}$ & Coefficient & $95 \% \mathrm{Cl}$ \\
\hline Age, years (continuous) & 0.06 & $0.01 ; 0.11$ & 0.04 & $-0.01 ; 0.10$ & 0.05 & $-0.01 ; 0.11$ & 0.04 & $-0.022 ; 0.10$ \\
\hline BMl, kg/m2 (continuous) & -0.09 & $-0.20 ; 0.01$ & -0.02 & $-0.24 ; 0.20$ & -0.08 & $-0.17 ; 0.01$ & 0.02 & $-0.16 ; 0.20$ \\
\hline Waist circumference, cm (continuous) & -0.04 & $-0.08 ; 0.00$ & -0.04 & $-0.12 ; 0.05$ & -0.04 & $-0.08 ; 0.00$ & -0.06 & $-0.13 ; 0.02$ \\
\hline Hypertension $(\mathrm{no}=0$, yes $=1$ ) & 1.77 & $0.35 ; 3.18$ & 1.86 & $0.41 ; 3.32$ & -2.38 & $-2.26 ; 1.78$ & -0.37 & $-2.46 ; 1.73$ \\
\hline Dyslipidemia $(\mathrm{no}=0$, yes $=1$ ) & -0.20 & $-1.30 ; 0.91$ & -0.53 & $-1.67 ; 0.61$ & -0.18 & $-1.43 ; 1.07$ & -0.39 & $-1.68 ; 0.90$ \\
\hline Diabetes $($ no $=0$, yes $=1$ ) & 0.37 & $-0.55 ; 1.29$ & 0.40 & $-0.54 ; 1.34$ & 1.18 & $0.16 ; 2.20$ & 1.56 & $0.48 ; 2.63$ \\
\hline \multicolumn{9}{|l|}{ Smoking status (never smoked $=0$ ) } \\
\hline Former smoker & 0.01 & $-1.00 ; 1.03$ & 0.01 & $-1.01 ; 1.03$ & 0.30 & $-1.67 ; 2.27$ & -0.12 & $-1.21 ; 0.96$ \\
\hline Current smoker & -2.53 & $-4.41 ;-0.66$ & -2.13 & $-4.03 ;-0.22$ & 0.64 & $-1.30 ; 2.58$ & -0.15 & $-2.14 ; 1.84$ \\
\hline
\end{tabular}

BALANCE = Brazilian Cardioprotective Nutritional Program 
saturated fat [34] and they should be consumed in small quantities in the BALANCE diet. Furthermore, the BALANCE diet encourages the intake of foods available and accessible in Brazil, which are not beneficial sources of MUFA, contrary to the reality of the Mediterranean region $[4,35]$.

Nevertheless, the relative participation of carbohydrate increases as the score in the index increases. This could be explained by the lower relative participation of total fat in the higher levels of the score. Because the amount of fiber was also positively associated with the index, another explanation for the higher quantities of carbohydrate in the top levels of the index is the high intake of fruits in the BALANCE diet (data not shown), which has, as a benefit, elevated amounts of vitamins and bioactive compounds with a cardioprotective role [36].

The higher percentage of protein among women in the 4th quartile of the index is an unexpected result. We have two possible explanations for that. First, the macronutrients are presented as a percentage of energy, which means that if the percentage of one macronutrient changes the others will consequently change. Thus, the higher amount of protein could be explained by the lower relative participation of total fat in the highest quartile of the index. Second, an increase in protein intake from green group foods (beans and legumes, fatfree milk and yoghurt) may also have led to this result.

We were not able to detect associations between the index and the intake of sodium. A possible explanation is the fact that the sodium intake was estimated from 24-h recalls, which is not a robust instrument for estimating sodium intake. The gold standard method to estimate sodium intake is the 24-h urinary excretion, but these data were not available. A previous study estimated sodium intake from semi-quantitative food frequency questionnaire and was also unable to detect an association between the DI and the intake of sodium [27].

In our study, we observed lower index scores among males smoking and higher scores among males with hypertension and females with diabetes. Previous studies did not find associations between hypertension and diabetes diagnosis and conformance with DI [32, 37], but found associations between DI and BMI, WC and smoking status $[29,32,33]$. It is important to highlight that these studies included patients without previous CVD, while BALANCE included patients in the secondary prevention. Thus, subjects from BALANCE trial may have already received nutritional advice from dieticians, doctors, and nurses before being enrolled in the trial, making them aware of the eating choices they should make. This is a possible explanation for having hypertensive and diabetics subjects with better index scores.

The present study has limitations. The diagnoses of diabetes, hypertension and dyslipidemia were self- reported. However, this is unlikely to have added bias to the study because participants are in the secondary prevention of cardiovascular disease, which requires them to take some medications daily. By the type of taken medication (antihypertensive, for example) patients and interviewers know their health condition.

Although the dietary data were collected by trained interviewers following standardized procedures and were submitted to quality control, the usual intake could not be estimated because we had only one 24-h recall. Usually intake is estimated with at least two 24-h recalls to soften the effects of within-person variance in the assessment of the diet-disease relationship. The present study described the development of a dietary index based on the BALANCE diet and did not assess diet-disease relationships. Furthermore, a single 24-h recall can characterize the average consumption of a group and can be used when the sample size is large (higher than 1000) [38].

The number of servings in the blue group is an upper limit, i.e. if the recommendation is two servings then two servings or less should be eaten, while foods in the red group are not supposed to be part of the diet. Blue and red groups are given a reverse score and there is no clear scientific evidence or logical value clarifying how high an intake should be to deserve the minimum score of zero. Thus, we decided to use data-driven cut-offs to avoid giving the maximum or minimum score to a large proportion of the population. The decision to use datadriven cut-offs could compromise the external validity of the index. It is also important to note that our findings are derived from a Brazilian population aged 45 years or older with a personal history of major cardiovascular events (stroke, coronary heart disease, peripheral vascular disease) and the BALANCE dietary index can characterise the diet of similar populations.

\section{Conclusion}

In this manuscript, we described the development of BALANCE DI and assessed some aspects of its validity, as well as population characteristics associated with higher or lower scores.

Regarding the internal consistency, BALANCE DI showed performance similar with other DI. The construct validity was corroborated by the ability to discriminate groups with known differences in the diet (males/ females). The positive association with the consumption of carbohydrate and fiber, probably reflecting the intake of fruits, and the inverse association with intakes of energy, total fat, MUFA and cholesterol reinforces the content validity. Concerning population characteristics, we observed that diabetic women and hypertensive men were more likely to have higher index scores while smoking males were more likely to have lower scores. 
The BALANCE DI has several potential uses: evaluation of the BALANCE Program dietary intervention; monitoring trial participants' compliance with the diet during the follow-up period; assessment of the association between the BALANCE diet and major CVD events; prediction of CVD risk (future). Before applying the index for all these purposes, we suggest studies with longitudinal designs to assess the validity of the index against health outcomes and its performance in detecting the relationship between overall diet and health.

\section{Abbreviations \\ BALANCE: Brazilian Cardioprotective Nutritional Program; BMI: Body mass index; Cl: Confidence interval; CVD: Cardiovascular disease; DI: Dietary index; MUFA: Monounsaturated fatty acids; SD: Standard deviation; USDA: United States Department of Agriculture; WC: Waist circumference; WHO: World Health Organization}

\section{Acknowledgements}

We thank all the researchers who work in the BALANCE trial. We thank Camila Zancheta Ricardo, Giovanna Calixto Andrade, Priscila Pereira Machado, Leandro Fornias Machado de Rezende and Lucas Damiani for their comments and contributions on the statistical analysis.

\section{Funding}

This manuscript reports a substudy of the BALANCE Program trial, which was funded by the Brazilian Ministry of Health in Partnership with the Research Institute of Hospital do Coração (HCor) — "Programa de Apoio ao Desenvolvimento Institucional do SUS (Brazilian Public Health System): PROADI-SUS". The funder had no influence on the study execution or manuscript writing.

\section{Availability of data and materials}

The data that support the findings of this study is from the BALANCE trial (https://www.clinicaltrials.gov/; NCT01620398) but restrictions apply to the availability of these data, which were used under license for the current study, and so are not publicly available. Data are however available from the authors upon reasonable request and with permission of the BALANCE trial Steering Committee.

\section{Authors' contributions}

JTS conceived and conducted the present study, analyzed data, drafted the manuscript and has primary responsibility for the final content. ACBF, CRT and BW provided the database from the BALANCE trial and contributed to the development of the dietary index. RBL designed the research, analysed data, performed statistical analysis, and critically revised the manuscript for important intellectual content. All authors have read and approved the final manuscript.

\section{Ethics approval and consent to participate}

The present analysis was approved by the School of Public Health / University of São Paulo Research Ethics Committee.

\section{Competing interests}

The authors declare that they have no competing interests.

\section{Publisher's Note}

Springer Nature remains neutral with regard to jurisdictional claims in published maps and institutional affiliations.

\section{Author details}

'Department of Nutrition, School of Public Health, University of São Paulo, Avenida Doutor Arnaldo, 715, São Paulo, SP 01246904, Brazil. ${ }^{2}$ Research Institute, Hospital do Coração (HCor), Rua Abílio Sorares, 250, $12^{\circ}$ andar, São Paulo, SP 04005-000, Brazil. ${ }^{3}$ Department of Preventive Medicine, School of Medicine, University of São Paulo, Avenida Doutor Arnaldo, 455, São Paulo, SP 01246903, Brazil.
Received: 6 October 2017 Accepted: 1 May 2018

Published online: 04 May 2018

\section{References}

1. World Health Statistics. Geneva: World Health Organization; 2015.

2. Mansur AP, Favarato D. Trends in mortality rate from cardiovascular disease in Brazil, 1980-2012. Arq Bras Cardiol. 2016;107:20-5.

3. Burlingame B, Dernini S. Sustainable diets and biodiversity: directions and solutions for policy, research and action. Rome, Italy: Nutrition and Consumer Protection Division FAO; 2012.

4. Weber B, Bersch-Ferreira Â, Torreglosa CR, Ross-Fernandes MB, da Silva JT, Galante AP, et al. The Brazilian Cardioprotective nutritional program to reduce events and risk factors in secondary prevention for cardiovascular disease: study protocol (the BALANCE program trial). Am Heart J. 2016;171:73-81. e2

5. Stefler D, Pikhart H, Jankovic N, Kubinova R, Pajak A, Malyutina S, et al. Healthy diet indicator and mortality in eastern European populations: prospective evidence from the HAPIEE cohort. Eur J Clin Nutr. 2014;68:1346-52.

6. Bach A, Serra-Majem L, Carrasco JL, Roman B, Ngo J, Bertomeu I, et al. The use of indexes evaluating the adherence to the Mediterranean diet in epidemiological studies: a review. Public Health Nutr. 2006;9:132-46.

7. Fung TT, Chiuve SE, McCullough ML, Rexrode KM, Logroscino G, Hu FB. Adherence to a DASH-style diet and risk of coronary heart disease and stroke in women. Arch Intern Med. 2008;168:713-20.

8. Roy R, Hebden L, Rangan A, Allman-Farinelli M. The development, application, and validation of a healthy eating index for Australian adults (HEIFA-2013). Nutrition. 2016;32:432-40.

9. Drake I, Gullberg B, Ericson U, Sonestedt E, Nilsson J, Wallström P, et al. Development of a diet quality index assessing adherence to the Swedish nutrition recommendations and dietary guidelines in the Malmö diet and Cancer cohort. Public Health Nutr. 2011;14:835-45.

10. McCullough ML, Feskanich D, Stampfer MJ, Giovannucci EL, Rimm EB, Hu FB, et al. Diet quality and major chronic disease risk in men and women: moving toward improved dietary guidance. Am J Clin Nutr. 2002;76:1261-71.

11. Moshfegh AJ, Rhodes DG, Baer DJ, Murayi T, Clemens JC, Rumpler WV, et al. The US Department of agriculture automated multiple-pass method reduces bias in the collection of energy intakes. Am J Clin Nutr. 2008;88:324-32.

12. Weber $B$, Berwanger $\mathrm{O}$, Costa RP, Lara EMS, Fernandes MBR, Ferreira ACB, et al. Álbum fotográfico de medidas e porções de alimentos. São Paulo: Instituto de Ensino e Pesquisa do Hospital do Coração; 2012.

13. Nielsen SJ, Adair L. An alternative to dietary data exclusions. J Am Diet Assoc. 2007;107:792-9.

14. Physical status: the use and interpretation of anthropometry: report of a WHO Expert. Geneva: World Health Organization; 1995.

15. Anales da 36a Reunión del Comité Asesor de Investigaciones en salud. Encuesta multicentrica: salud, bien estar y envejecimiento (SABE) en América Latina y el Caribe.mayo 2001; Washington (DC): Wold Health Organization

16. Sociedade Brasileira de Cardiologia. IV Diretriz da Sociedade Brasileira de Cardiologia sobre Tratamento do Infarto Agudo do Miocárdio com Supradesnível do Segmento ST. Arq Bras Cardiol. 2009;93(Suppl 2):179-264.

17. Sociedade Brasileira de Hipertensão, Sociedade Brasileira de Cardiologia, Sociedade Brasileira de Endocrinologia e Metabologia, et al. I Brazilian guidelines on diagnosis and treatment of metabolic syndrome. Arq Bras Cardiol. 2005;84(Suppl 1):1-28.

18. Sociedade Brasileira de Cardiologia. V Diretriz Brasileira Sobre Dislipidemias e Prevenção da Aterosclerose Departamento de Aterosclerose da Sociedade Brasileira de Cardiologia. Arq Bras Cardiol. 2013;101(Suppl1):1-22.

19. Sociedade Brasileira de Cardiologia, Sociedade Brasileira de Hipertensão, Sociedade Brasileira de Nefrologia. VI Brazilian guidelines on hypertension. Arq Bras Cardiol. 2010;95(Suppl 1):1-51.

20. Sociedade Brasileira de Diabetes. Diretrizes da Sociedade Brasileira de Diabetes (2015-2016). São Paulo: Sociedade Brasileira de Diabetes; 2016.

21. Drewnowski A, Fulgoni VL. Nutrient density: principles and evaluation tools. Am J Clin Nutr. 2014;99(Suppl):1223-8.

22. Miller PE, Cross AJ, Subar AF, Krebs-Smith SM, Park Y, Powell-Wiley T, et al. Comparison of 4 established DASH diet indexes: examining associations of index scores and colorectal cancer. Am J Clin Nutr. 2013;98:794-803.

23. Kennedy ET, Ohls J, Carlson S, Fleming K. The healthy eating index: design and applications. J Am Diet Assoc. 1995;95:1103-8. 
24. Panagiotakos DB, Pitsavos C, Stefanadis C. Dietary patterns: a mediterranean diet score and its relation to clinical and biological markers of cardiovascular disease risk. Nutr Metab Cardiovasc Dis. 2006;16:559-68.

25. Guenther PM, Kirkpatrick SI, Reedy J, Krebs-Smith SM, Buckman DW, Dodd KW, et al. The healthy eating Index-2010 is a valid and reliable measure of diet quality according to the 2010 dietary guidelines for Americans. J Nutr. 2014;144:399-407.

26. Najas M. I Consenso Brasileiro de Nutrição e Disfagia em Idosos Hospitalizados. Barueri, SP: Sociedade Brasileira de Geriatria e Gerontologia; 2011.

27. Brasil, Ministério da Saúde. Vigitel Brazil 2014: protective and risk factors for chronic diseases by telephone survey. Brasília: Ministério da Saúde; 2015.

28. Guenther PM, Reedy J, Krebs-Smith SM. Development of the healthy eating Index-2005. J Am Diet Assoc. 2008;108:1896-901.

29. McNaughton SA, Ball K, Crawford D, Mishra GD. An index of diet and eating patterns is a valid measure of diet quality in an Australian population. $J$ Nutr. 2008;138:86-93.

30. Mendes A, Gavioli L, Previdelli AN, Fisberg RM, Marchioni DML. The diet quality index evaluates the adequacy of energy provided by dietary macronutrients. Revista de Nurição. 2015;28:7.

31. de Andrade SC, Previdelli AN, Marchioni DML, Fisberg RM. Avaliação da confiabilidade e validade do Índice de Qualidade da Dieta Revisado. Rev Saude Publica. 2013:47:8.

32. Fogli-Cawley JJ, Dwyer JT, Saltzman E, McCullough ML, Troy LM, Jacques PF. The 2005 dietary guidelines for Americans adherence index: development and application. J Nutr. 2006;136:2908-15.

33. Schroder H, Fito M, Estruch R, Martinez-Gonzalez MA, Corella D, SalasSalvado J, et al. A short screener is valid for assessing Mediterranean diet adherence among older Spanish men and women. J Nutr. 2011;141:1140-5.

34. Schwingshackl L, Hoffmann G. Monounsaturated fatty acids, olive oil and health status: a systematic review and meta-analysis of cohort studies. Lipids Health Dis. 2014;13:154.

35. Estruch R, Ros E, Salas-Salvadó J, Covas MI, Corella D, Arós F, et al. Primary prevention of cardiovascular disease with a Mediterranean diet. N Engl J Med. 2013;368:1279-90.

36. Alissa EM, Ferns GA. Functional foods and nutraceuticals in the primary prevention of cardiovascular diseases. J Nutr Metab. 2012; https://doi.org/10. $1155 / 2012 / 569486$

37. Bhupathiraju SN, Lichtenstein AH, Dawson-Hughes B, Tucker KL. Adherence index based on the AHA 2006 diet and lifestyle recommendations is associated with select cardiovascular disease risk factors in older Puerto Ricans. J Nutr. 2011;141:460-9.

38. Willett W. Nutritional epidemiology. 3rd ed. New York: Oxford University Press; 2012.

\section{Ready to submit your research? Choose BMC and benefit from:}

- fast, convenient online submission

- thorough peer review by experienced researchers in your field

- rapid publication on acceptance

- support for research data, including large and complex data types

- gold Open Access which fosters wider collaboration and increased citations - maximum visibility for your research: over $100 \mathrm{M}$ website views per year 